\title{
Carcinoma fusocelular de cavidad oral. Revisión de 9 casos
}

\author{
Spindle cell carcinoma of the oral cavity. A review of 9 cases
}

\author{
G. Gómez Oliveira', J. Ferreras Granado², L.M. Junquera Gutiérrez³
}

Resumen: El carcinoma fusocelular es una variedad maligna y poco frecuente del carcinoma de células escamosas. Es una tumoración constituida por una doble proliferación celular: una sarcomatosa de células fusocelulares y otra carcinomatosa de células epiteliales. Aunque puede afectar a cualquier parte del organismo, es más frecuente encontrarla en vías aerodigestivas superiores. Afecta con mayor frecuencia a varones entre la $6^{\mathrm{a}}$ y $7^{\mathrm{a}}$ décadas de la vida. Tiene un comportamiento agresivo con tendencia a la recurrencia. El alcohol y tabaco han sido identificados como los factores de riesgo más importantes. Su diagnóstico histológico es complicado y muchas veces es necesario recurrir a técnicas de inmunohistoquímica y al uso del microscopio electrónico. En la actualidad, se le atribuye un origen epitelial.

El objetivo de este trabajo es presentar una revisión de 9 casos de carcinoma fusocelular localizados en cavidad oral recogidos en nuestro servicio entre los años 1985 a 2004, describiendo su comportamiento clínico y tratando de comprender la patogenia de esta controvertida estirpe tumoral.

Palabras clave: Carcinoma fusocelular; Cavidad oral; Inmunohistoquímica; tumor bifásico; Origen epitelial.

Recibido: 15.02.2005

Aceptado: 23.01.2006

\begin{abstract}
Spindle cell carcinoma is a malignant and rare variant of squamous cell carcinoma. The histological pattern is composed of a double cell proliferation: a sarcomatous component made up of spindle-shaped cells and a carcinomatous component made up of epithelial cells. Nearly all the anatomy of the body can be affected by these tumors although the most common location is the upper aerodigestive tract. With regard to sex distribution, it is more frequent in males than in females in their sixth and seventh decades of life. Its behavior is aggressive and it tends to recur after treatment. The most important risk factors are alcohol and tobacco. The histological diagnosis is complicated, so immunohistochemical techniques and the use of electron microscopy are usually necessary. Nowadays, its epithelial origin is accepted.

The aim of this article is to report a retrospective study of 9 cases of oral cavity spindle cell carcinoma treated in our service of Oral and Maxillofacial Surgery, between 1985 and 2004. We describe the clinical behavior and the pathogeny of this tumor.
\end{abstract}

Key words: Spindle cell carcinoma; Oral cavity; Immunohistochemical; Biphasic tumor; Squamous origin.

\footnotetext{
1 Médico Residente.

2 Médico Adjunto.

Complejo Hospitalario Universitario Juan Canalejo. La Coruña, España

3 Médico Adjunto. Hospital Central Universitario de Asturias, Oviedo, España
}

Correspondencia:

C/ Almirante Mourelle $292^{\circ}$

15011 La Coruña, España

E-mail: guis@canalejo.org 


\section{Introducción}

El carcinoma fusocelular es una variante maligna y muy poco frecuente del carcinoma epidermoide..$^{1-4}$ Se caracteriza por una proliferación simultánea de células epiteliales malignas y células fusiformes de tipo sarcomatoso, por lo que se considera un tumor bifásico.1-3,5-7 Este tipo de crecimiento ha generado diversas hipótesis sobre su origen y comportamiento, lo que se refleja en la variada terminología utilizada para designarlo: carcinoma fusocelular, pseudosarcoma, carcinosarcoma, carcinoma de células escamosas pseudosarcomatoso, carcinoma sarcomatoso, carcinoma metaplásico, carcinoma fusocelular, carcinoma pleomórfico, carcinoma epidermoide - variedad de células fusiformes. .11 $^{71}$

En la actualidad se le atribuye un origen epitelial, 1,4 aunque algunos autores siguen dudando de ello.12-14 Puede localizarse en cualquier epitelio corporal, aunque las vías aerodigestivas superiores, laringe y cavidad oral, son su lugar de asiento más frecuente, siendo la piel, el esófago y los senos paranasales localizaciones menos frecuentes. $1,2,8,9,15,16$

\section{Material y método}

Entre los años 1985-2004 se han recogido 9 casos de carcinoma fusocelular de cavidad oral (primario o en recidivas) en nuestro servicio. El tiempo de seguimiento varió desde los 6 meses a los 19 años.

El objetivo de este trabajo es realizar un estudio descriptivo de nuestra casuística describiendo su comportamiento clínico y tratando de comprender la patogenia de esta controvertida estirpe tumoral.

\section{Resultados}

De los 9 pacientes, 5 fueron varones y 4 mujeres. La edad de los pacientes osciló entre 43 y 82 años, con una media de 59 años. Cuatro de ellos $(44,4 \%)$ tenían una historia previa de tabaquismo y otros cuatro $(44,4 \%)$ presentaban leucoplasia oral. Un sólo paciente tenía antecedentes de abuso de alcohol (Tabla 1). Hemos observado una relación entre sexo femenino y ausencia de factores de riesgo. La presencia de una tumoración dolorosa fue el signo clínico más frecuente $(55,5 \%)$. La tumoración fue de tipo vegetante en 5 casos, ulcerosa en 3 y ulcero-vegetante en un solo caso. La localización inicial más frecuente correspondió a la lengua (4 en borde lateral y uno en dorso), seguido de trígono retromolar (2 casos), mucosa yugal (1 caso) y encía lingual (1 caso).

En cuanto a la estadificación tumoral, 2 casos se clasificaron como estadio I $\left(\mathrm{T}_{1} \mathrm{~N}_{0} \mathrm{M}_{0}\right), 3$ como estadio II $\left(\mathrm{T}_{2} \mathrm{~N}_{0} \mathrm{M}_{0}\right)$ y 4 como estadio IV ( 3 como $\mathrm{T}_{4} \mathrm{~N}_{0} \mathrm{M}_{0}$ y 1 como $\mathrm{T}_{2} \mathrm{~N}_{2} \mathrm{bM}_{0}$ ).

El resultado anatomopatológico tras el tratamiento inicial recogió 4 carcinomas epidermoides y 5 carcinomas fusocelulares ó con áreas de carcinoma fusocelular. En las recidivas posteriores de los 4 casos etiquetados inicialmente como carcinomas epidermoides se encontraron áreas de carcinoma fusocelular (Tabla 2).

\section{Introduction}

Spindle cell carcinoma is a malignant variant of squamous cell carcinoma that is very rare. ${ }^{1-4}$ It is characterized by the simultaneous proliferation of malignant epithelial cells and spindle cells of a sarcomatous type, and it is thus considered a biphasic tumor. ${ }^{1-3,5-7}$ This type of growth has generated various hypotheses as to its origin and behavior, which is reflected in the varied terminology used for designating it: spindle cell carcinoma, pseudosarcoma, carcinosarcoma, pseudosarcomatous squamous cell carcinoma, sarcomatoid carcinoma, metaplastic carcinoma, pleomorphic carcinoma, spindle cell squamous carcinoma. . $11^{-11}$

Currently it is thought to have an epithelial origin, 1,4 although some authors are still dubious about this. 12.14 It can be found in any part of the epithelium of the body, although it is most commonly found in the upper aerodigestive tract, larynx and oral cavity. More rarely it is to be found in the skin, esophagus and paranasal sinuses. $1,2,8,9,15,16$

\section{Material and method}

Between 1985 and 2004 nine cases of spindle cell carcinoma of the oral cavity (primary or recurring) were registered in our department. The follow-up varied between 6 months and 19 years.

The object of this work is to carry out a descriptive study of these cases describing the clinical behavior while trying to understand the pathogeny behind the controversial lineage of this tumor.

\section{Results}

Of the nine patients, five were males and four were females. The age of the patients varied between 43 and 82 years, with a mean age of 59 years. Four (44.4\%) had a previous history of smoking and another four $44.4 \%$ had oral leukoplasia. Only one patient had a history of alcohol abuse (Table 1). We observed a link between the female sex and the absence of risk factors. The presence of a painful tumor-like mass was the most common manifestation (55.5\%). The tumor was of the vegetative type in five cases, ulcerous in three and ulcero-vegetative in just one case. Initially the most common location was on the tongue (four on the lateral border and one on the back), followed by the retromolar trigone (two cases) jugal mucosa (one case) and the lingual gingiva (one case).

With regard to tumor stage, two cases were classified as stage I $\left(T_{1} N_{0} M_{0}\right)$, three as stage II $\left(T_{2} N_{0} M_{0}\right)$ and four as stage IV (three as $T_{4} N_{0} M_{0}$ and one as $T_{2} N_{2 b} M_{0}$ ).

The anatomopathologic result after the initial treatment reported four squamous cell carcinomas, and five spindle cell carcinomas or with areas of spindle cell carcinoma. In the 
Se produjeron un total de 12 recidivas tumorales en 5 de los 9 pacientes, la gran mayoría con un carcinoma epidermoide como neoplasia primaria. En tres casos se produjo una primera recidiva en forma de carcinoma epidermoide y las posteriores en forma de carcinoma fusocelular. En un paciente se produjo una primera recidiva en forma de carcinoma fusocelular y dos posteriores como carcinoma epidermoide. En otro caso la única recidiva observada correspondió a un carcinoma epidermoide. La localización más habitual fue el suelo de boca (50\%), seguido por la lengua (34\%). El tratamiento de elección de las recidivas fue el quirúrgico. Sólo uno de los pacientes que inicialmente fueron diagnosticados de carcinoma fusocelular presentó recidiva tumoral local en forma de carcinoma epidermoide.

\section{Discusión}

El carcinoma fusocelular es una neoplasia maligna rara que afecta fundamentalmente a varones (relación varón: mujer 4-10:1) entre 50 y 70 años de edad según los distintos estudios. ${ }^{1-5,17-20}$ En nuestra serie no encontramos esa relación (1.25:1). Consideramos relevante el hecho de no haber encontrado ningún factor de riesgo entre las mujeres.

Está constituida por dos tipos celulares: el componente epitelial suele ser minoritario y la imagen histológica varía entre displasia y carcinoma epidermoide. 5,7,17-19 Los signos de queratinización suelen ser escasos ó estar ausentes. ${ }^{4}$ El componente principal es el sarcomatoso ${ }^{2,6,18} \mathrm{y}$, en ocasiones, se pueden identificar áreas de tran-

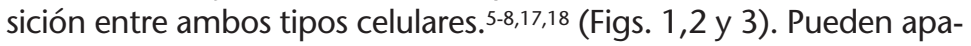
recer elementos heterólogos osteo, condro ó rabdomiosarcomato$\operatorname{sos}^{17,19}$ que parecen estar asociados con radioterapia previa. ${ }^{17}$

Entre los factores predisponentes se recogen en la literatura el consumo de tabaco y alcohol, la mala higiene oral, la exposición al sol, 1,8-10,15,17,19-21 las radiaciones ${ }^{7-9,17,19-21}$ y traumatismos previos. , $4^{4}$ Se ha observado asimismo, que este tumor asienta con mayor frecuencia sobre cicatrices cutáneas secundarias a quemaduras.1,4 Incluso se ha llegado a describir un caso en relación a un quiste odontogénico. 22 Esto concuerda con los resultados observados en nuestra serie, en donde los factores de riesgo más importantes son el later recurrences of the four cases initially labeled as squamous cell carcinoma, areas of spindle cell carcinoma were found (Table 2).

There were a total of 12 cases of tumor recurrence in five out of the nine patients, most with squamous cell carcinoma as a primary neoplasm. In three cases there was an initial recurrence in the form of squamous cell carcinoma and later in the form of spindle cell carcinoma. In one patient there was an initial recurrence in the form of spindle cell carcinoma followed by two later recurrences in the form of squamous cell carcinoma. The most common location was on the floor of the mouth (50\%), followed by the tongue (34\%). The treatment of choice for these recurrences was surgical. Only one patient that was initially diagnosed with spindle cell carcinoma experienced local tumor recurrence in the form of squamous cell carcinoma.

\section{Discussion}

Spindle cell carcinoma is a rare malignant neoplasm that mainly affect males (male: female ratio 4-10:1) between the age of 50 and 70 according to the different studies. ${ }^{1-5,17-20}$ In our series we did not find this relationship (1.25:1). It is of relevance that no risk factor was found among the women.

Spindle cell carcinoma is made up of two cellular types: the epithelial component tends to be in a minority and the histological image varies between dysplasia and squamous cell carcinoma.5,7,17-19 There tends to be little or no evidence of keratinization. ${ }^{4}$ The principal component is sarcomatous $2,6,18$ and, on occasions, transitional areas between both cellular types can be identified.5-8,17,18 (Figs. 1,2 and 3). Het- 
tabaco y el alcohol. Encontramos una elevada incidencia de leucoplasias en nuestra casuística, hecho no encontrado en la bibliografía consultada.

Los factores pronósticos implicados incluyen la invasión en profundidad del tumor, 2,19,20,21,23,24 localización, 9,18,23,25,26 metástasis ganglionares cervicales, $, 918,20,25,26$ tamaño tumoral9,18,19 y del componente carcinomatoso, 12 TPI (correlación con la supervivencia), grado de diferenciación, 18,19 positividad para queratina, ${ }^{19}$ estadio $^{23}$ y morfología tumoral. ${ }^{26}$

Se suele presentar como una masa exofítica, polipoidea, de crecimiento rápido, con la superficie ulcerada, siendo menos frecuente su manifestación como masa sesil, nodular o endofítica. $2,4,6,8-10,17-19,25$ Su comportamiento clínico es agresivo, 5,8,9,15,23,26 fundamentalmente si es de localización intraoral ${ }^{10,21}$ y aparece en pacientes previamente radiados. Manifiesta una gran tendencia a dar metástasis tanto linfáticas, las más frecuentes, como a distancia. ${ }^{2,4,8}$ Batsakis y cols ch $^{25}$ (1981), recogen 111 casos de carcinoma fusocelular de vías aerodigestivas superiores, demostrando una tasa de metástasis linfáticas del 24\%. Otras series han encontrado metástasis linfáticas hasta en el $50 \%$ de los casos. ${ }^{27}$ Estas metástasis pueden ser epiteliales, sarcomatosas o mixtas. $2,6,8,9,19,28$ Presentan, asimismo, una alta tasa de recurrencia local.8, 17,21,27,28 La mortalidad es elevada y oscila entre el 24 y el $90 \%$ según autores. $17,21,25$

El origen de este tumor ha sido un tema muy controvertido durante los últimos años. Existen varias teorías sobre su génesis. La primera de ellas es defendida por Lane $^{12}$ en 1957. Este autor cree que se trata de una reacción benigna en respuesta a un carcinoma epidermoide adyacente. Sherwin ${ }^{14}$ (1963) piensa que es una combinación de una reacción benigna reactiva y una variante de carcinoma epidermoide, mientras que

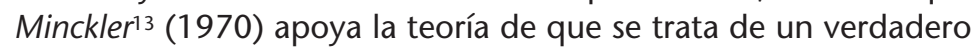

Tabla 2. Anatomía patológica

Table 2. Pathological anatomy

\begin{tabular}{|c|c|c|}
\hline Paciente & Anatomía final & Anatomía de recidivas \\
\hline 1 & $\begin{array}{l}\text { Carcinoma epidermoide } \\
\text { con áreas fusocelulares }\end{array}$ & \\
\hline 2 & Carcinoma fusocelular & \\
\hline 3 & $\begin{array}{l}\text { Carcinoma fusocelular con } \\
\text { patrón pseudosarcomatoso }\end{array}$ & \\
\hline 4 & Carcinoma epidermoide & $\begin{array}{c}\text { Carcinoma epidermoide } \\
\text { poco diferenciado } \\
\text { Carcinoma fusocelular }\end{array}$ \\
\hline 5 & Carcinoma fusocelular & \\
\hline 6 & $\begin{array}{l}\text { Carcinoma epidermoide con } \\
\text { áreas fusocelulares }\end{array}$ & $\begin{array}{l}\text { Carcinoma epidermoide } \\
\text { poco diferenciado }\end{array}$ \\
\hline \multirow[t]{4}{*}{7} & $\begin{array}{l}\text { Carcinoma epidermoide } \\
\text { poco diferenciado }\end{array}$ & Carcinoma epidermoide \\
\hline & & Carcinoma epidermoide \\
\hline & & Carcinoma epidermoide \\
\hline & & $\begin{array}{l}\text { Carcinoma epidermoide con } \\
\text { patrón pseudosarcomatoso }\end{array}$ \\
\hline \multirow[t]{2}{*}{8} & $\begin{array}{c}\text { Carcinoma epidermoide } \\
\text { moderadamente diferenciado }\end{array}$ & Carcinoma fusocelular \\
\hline & & $\begin{array}{l}\text { Carcinoma epidermoide } \\
\text { Carcinoma epidermoide }\end{array}$ \\
\hline 9 & $\begin{array}{l}\text { Carcinoma epidermoide } \\
\text { bien diferenciado }\end{array}$ & $\begin{array}{l}\text { Carcinoma epidermoide } \\
\text { Carcinoma fusocelular }\end{array}$ \\
\hline
\end{tabular}

\begin{tabular}{|c|c|c|}
\hline Patient & Final anatomy & Recurrence anatomy \\
\hline 1 & $\begin{array}{l}\text { Squamous cell carcinoma } \\
\text { with spindle cell areas }\end{array}$ & \\
\hline 2 & Spindle cell carcinoma & \\
\hline 3 & $\begin{array}{l}\text { Spindle cell carcinoma with } \\
\text { a pseudosarcomatous pattern }\end{array}$ & \\
\hline 4 & Squamous cell carcinoma & $\begin{array}{l}\text { Poorly differentiated } \\
\text { squamous cell carcinoma } \\
\text { Spindle cell carcinoma }\end{array}$ \\
\hline 5 & Spindle cell carcinoma & \\
\hline 6 & $\begin{array}{c}\text { Squamous cell carcinoma with } \\
\text { spindle cell areas }\end{array}$ & $\begin{array}{c}\text { Poorly differentiated } \\
\text { squamous cell carcinoma }\end{array}$ \\
\hline \multirow[t]{4}{*}{7} & $\begin{array}{l}\text { Poorly differentiated } \\
\text { squamous cell carcinoma }\end{array}$ & Squamous cell carcinoma \\
\hline & & Squamous cell carcinoma \\
\hline & & Squamous cell carcinoma \\
\hline & & $\begin{array}{l}\text { Squamous cell carcinoma with } \\
\text { a pseudosarcomatous pattern }\end{array}$ \\
\hline \multirow[t]{3}{*}{8} & $\begin{array}{l}\text { Moderately differentiated } \\
\text { squamous cell carcinoma }\end{array}$ & Spindle cell carcinoma \\
\hline & & Squamous cell carcinoma \\
\hline & & Squamous cell carcinoma \\
\hline 9 & $\begin{array}{c}\text { Well differentiated } \\
\text { squamous cell carcinoma }\end{array}$ & $\begin{array}{l}\text { Squamous cell carcinoma } \\
\text { Spindle cell carcinoma }\end{array}$ \\
\hline
\end{tabular}

erologous osteo-, chondro- or rhabdomyosarcomatous elements can appear $^{17,19}$ that are associated with previous radiotherapy. ${ }^{17}$

Among the factors related to a predisposition that are recorded in the literature are cigarette and alcohol consumption, bad oral hygiene, exposure to the sun1,8-10,15,17,19-21, radiations ${ }^{7-9,17,19-21}$ and previous trauma. ${ }^{1,4}$ Likewise, it has been observed that this tumor is to be found more commonly on skin scars that are secondary to burns. ${ }^{1,4} \mathrm{~A}$ case in conjunction with an odontogenic cyst has also been described. 22 This is in agreement with the results observed in our series, in which the most important risk factors are tobacco and alcohol. We have found a high incidence of leukoplasia in these cases, a fact that was not reflected in the bibliography referred to.

The prognostic factors include deep invasion of the tumor, 2,19,20,21,23,24 location, 9, 18,23,25,26 metastasis to cervical lymph nodes, 9, 18,20,25,26 tumor size $e^{9,18,19}$ and the carcinomatous component, $12 \mathrm{TPI}$ (correlation with survival), degree of differentiation, ${ }^{18,19}$ keratin positivity, ${ }_{19}^{19}$ staging 23 and tumor morphology. ${ }^{26}$

It tends to appear as an exophytic, polypoidal quicklygrowing mass, with an ulcerated surface, and more unusually it will appear as a sessile, nodular or endophytic mass. 2,4,6,8-10,17-19,25 It is associated with aggressive clinical 
sarcoma. Leventon ${ }^{21}$ y Zarbo ${ }^{29}$ consideran que el tumor se origina de una célula madre pluripotencial que podría exhibir diferenciación tanto mesenquimal como epitelial, llegando incluso a sugerir que el componente sarcomatoso representa una alteración metaplásica del componente espinocelular, ${ }^{1}$ de ahí el nombre de carcinosarcoma. Ellis y cols ${ }^{16}$ (1987), creen que el tumor se origina a partir de una célula epitelial que ha sufrido una pérdida en la expresión de queratina, de ahí el nombre de carcinoma fusocelular.

En la actualidad, la teoría más aceptada es la que plantea un origen epitelial. ${ }^{10,18,21}$ Uno de los datos que la apoyan es la observación histológica de una transición, dentro del mismo tumor, del componente epidermoide hacia el fusocelular. En nuestra serie encontramos varios casos de esta transición, tanto de carcinoma epidermoide hacia carcinoma fusocelular como a la inversa.

Estudios histológicos y ultraestructurales demuestran la conservación de marcadores de diferenciación epitelial en las células fusocelulares, tanto citokeratinas $2,3,6,7,11,15,17,18,23,26$ como tonofilamentos, desmosomas y agregados de queratohialina.4,7,18,20,23 A este respecto, Lauwers y cols ${ }^{18}$ (1998) publican una serie de 13 casos de carcinoma fusocelular esofágico de los que 12 (95\%) presentaban positividad para citokeratina.

En 1996, Thompson, 30 consigue demostrar similaridades geno y fenotípicas entre los dos tipos celulares mediante estudios de ADN. Se ha demostrado que en ambas líneas celulares existe una alteración común tanto en la expresión del gen supresor p53 6,7 como en la de ciclina D1 (regulador del ciclo celular) 24 lo que sugiere que ambas alteraciones juegan un papel en la patogénesis molecular de este tumor y apoyan la idea de un origen común. Ansari-Lari y cols $\mathrm{s}^{7}$ confirman el origen monoclonal de la neoplasia al demostrar patrones de inactivación del cromosoma X y aberraciones cromosómicas idénticas.

Slootweg y cols ${ }^{11}$ (1989) relacionan la expresión de queratina con el fenotipo celular. Al respecto, observaron que en dos casos de carcinoma epidermoide que recidivaron como carcinomas fusocelulares había una menor expresión de esta proteína, mientras que en un caso de carcinoma fusocelular que recidivó como carcinoma epidermoide había una mayor expresión dela misma. Basándonos en

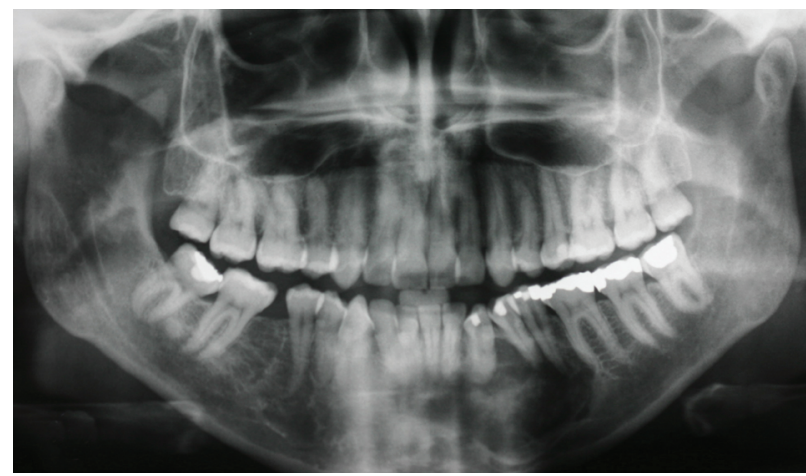

Figura 1. Patrón de crecimiento constituido por células fusiformes pleomórficas con núcleos con cromatina densa, nucleolos patentes y numerosas mitosis atípicas.

Figure 1. Growth pattern composed of pleomorphic spindle cells with nuclei with dense chromatin, prominent nucleoli and numerous aty
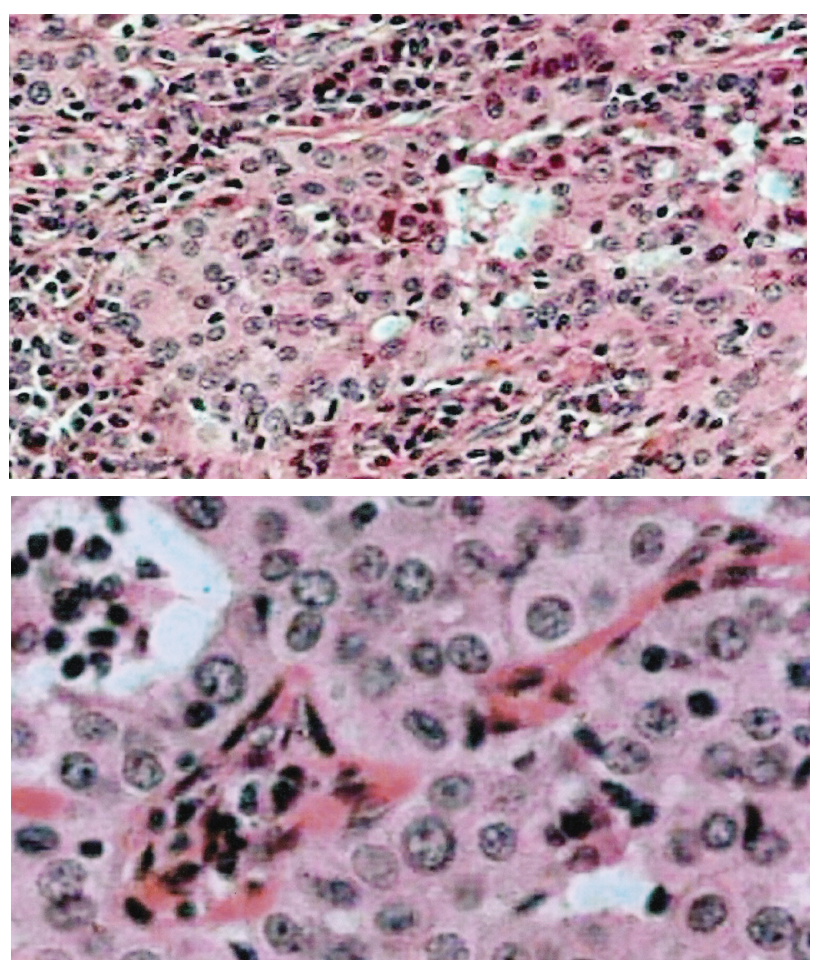

Figuras 2 y 3 . Superficie del tumor con áreas de clara diferenciación epidermoide rodeadas por áreas sarcomatosas.

Figures 2 y 3. Tumor surface with clearly defined squamous areas surrounded by sarcomatous areas. behavior $5,8,9,15,23,26$ if it has, fundamentally, an intraoral location, 10,21 and it appears in previously irradiated patients. It has a strong tendency to metastasize more commonly to the lymph nodes, or distantly. 2,4,8 Batsakis y cols 25 (1981) presented 111 cases of spindle cell carcinoma of the upper aerodigestive tract, and they reported a rate of lymphatic metastasis of $24 \%$. Other series found lymphatic metastasis in up to $50 \%$ of cases. ${ }^{27}$ These metastases can be epithelial, sarcomatoid or mixed. $2,6,8,9,19,28$ There is a high rate of local recurrence. $8,17,21,27,28$ The mortality rate is high and it varies between 24 and 90\% depending on the authors. ${ }^{17,21,25}$

The origin of this tumor has been very controversial over the last years. There are various theories as to its genesis. The first was put forward by Lane $^{12}$ in 1957. This author believes that it is a benign reaction in response to an adjacent squamous cell carcinoma. Sherwin ${ }^{14}$ (1963) believes that it is a combination of a reactive benign reaction and a variant of squamous cell carcinoma, while Minckler'13 (1970) supports the theory that it is in fact a true sarcoma. Leventon ${ }^{21}$ and Zarbo ${ }^{29}$ consider that the tumor originates from a pluripotential stem cell that could exhibit both mesenchymal and epithelial differentiation, and they have even suggested that the sarcomatous component represents a metaplastic alteration of the spinocellular component, ${ }^{1}$ thus the name carcinosarcoma. Ellis and cols ${ }^{16}$ (1987) believe that the tumor originates from epithelial cell loss during keratin expression, thus the name spindle cell carcinoma.

Currently, the theory that is most accepted is the one that points to an epithelial origin. 10,18,21 Supporting this theory is the histological observation of a transition within the 
la observación retrospectiva de nuestra serie creemos que el origen de este tumor es epitelial.

Aceptado el origen epitelial de la neoplasia, los estudios más recientes se centran en conocer cuales son las alteraciones que ocurren a nivel molecular. Las células epiteliales expresan citoqueratina, e-caderina (molécula de adhesión intercelular), alfa y beta cateninas (moléculas del citoplasma celular) ${ }^{1}$ y EMA (antígeno epitelial de membrana) ${ }^{2}$ mientras que las fusocelulares expresan preferentemente vimentina (marcador de células sarcomatosas) y disminuyen la expresión de citoqueratinas y E-caderinas. ${ }^{1,2,6,11,15,17,26}$ Se cree que tanto la disminución ó pérdida de E-caderina como la expresión heterogénea de alfa y beta cateninas son las responsables de que se pierda la adhesión intercelular, lo que provoca un cambio en la morfología celular de epidermoide a fusocelular, permitiendo un patrón de crecimiento más difuso e infiltrativo, justificando así la agresividad y metástasis de este tumor.1,2,6,18 La bibliografía consultada coincide en que todas las células fusocelulares expresan vimentina, mientras que porcentajes variables de éstas expresan citokeratinas, 1,2,6,11,15,17 lo cual nos lleva a pensar que el cambio de morfología que pueden sufrir estas estirpes celulares se ve influenciado por la expresión de estas y otras moléculas tanto de membrana como del citoplasma.

Lauwers y cols ${ }^{18}$ (1998) encuentran que el componente sarcomatoso presenta áreas más aneuploides que el carcinomatoso, y una mayor actividad biológica midiendo el TPI (Índice de proliferación tumoral) mediante inmunorreactividad, obteniendo valores de 0,44 para las zonas epidermoides y de 0,68 para las fusocelulares. Describen además un patrón de ADN diferente, encontrando zonas de baja ploidía para las áreas escamosas y zonas de baja y alta ploidía para las áreas fusocelulares. Ello indica un comportamiento clínico más agresivo. ${ }^{6}$

\section{Conclusiones}

El carcinoma fusocelular es una rara variedad de carcinoma de células escamosas al que se le atribuye un origen epitelial.. Es más frecuente encontrarla en vías aerodigestivas superiores. Presenta un comportamiento agresivo con una no desdeñable tasa de metástasis regionales. Su diagnóstico histológico es complicado y muchas veces es necesario recurrir a técnicas de inmunohistoquímica y al uso del microscopio electrónico.

\section{Agradecimientos}

Al Dr. Ferreras Granado por su ayuda e interés mostrado en la confección de este trabajo.

\section{Bibliografía}

1. Shibuya Y, Umeda M, Yokoo S, Komori T. Spindle Cell Squamous Carcinoma of the Maxilla: Report of a Case With Inmunohistochemical Analysis. J Oral MaxiIlofac Surg 2000;58:1164-9 tumor itself, of the squamous component to a spindle one. In our series we found various cases of this transition, of squamous cell carcinoma to spindle cell carcinoma as well as the reverse.

Histological and ultrastructural studies show the conservation of epithelial differentiation markers in spindle cells, of cytokeratins $2,3,6,7,11,15,17,18,23,26$ as well as of tonofilaments, desmosomes and keratohyaline aggregates, $4,7,18,20,23$ Likewise, Lauwers and cols's (1998) published a series of 13 cases of fusocellular carcinoma of the esophagus in which 12 (95\%) showed cytokeratin positivity.

In 1996, Thompson and cols. ${ }^{30}$ were able to show genoand phenotypic similarities between both cellular types by means of a DNA study. It has been demonstrated that in both cell lines there is a common disturbance in the expression of the supressor gene p536,7 as well as in cyclin D1 (a cell-cycle regulator), ${ }^{24}$ which suggests that both disturbances play a role in the molecular pathogenesis of this tumor, and they support the idea of a common origin. Ansari-Lari and cols ${ }^{7}$ confirm the monoclonal origin of the neoplasm on showing inactivation patterns of the $X$ chromosome and identical chromosome aberrations.

Slootweg and cols ${ }^{11}$ (1989) related the expression of keratin with the cellular phenotype. In this respect they observed that in two cases of squamous cell carcinoma that recurred as spindle cell carcinoma there was a lower expression of this protein, while in one case of spindle cell carcinoma that recurred as squamous cell carcinoma, the expression was higher. Based on the retrospective observation in our series we believe that the origin of this tumor is epithelial.

Now that the epithelial origin of the neoplasm has been accepted, the most recent studies endeavor to find out the disturbances that occur on a molecular level. Epithelial cells express cytokeratin, e-cadherin (intercellular adhesion molecule), alpha- and beta-catenins (molecules of cell cytoplasm) ${ }^{1}$ and EMA (epithelial membrane antigen), ${ }^{2}$ while spindle cells preferably express vimentin (a marker of sarcomatous cells), and the expression of cytokeratins and E-cadherin is diminished. $1,2,6,11,15,17,26$ It is thought that the reduction or loss of E-cadherin as well as the heterogeneous expression of alpha- and beta-catenins are responsible for the loss of intercellular adhesion, which will lead to the cellular morphology changing from squamous to spindle shape. This permits a growth pattern that is more diffuse and infiltrative, thus explaining the aggressiveness and metastasis of this tumor. 1,2,, 18 In the literature referred to, there is agreement on all spindle cells expressing vimentin, and a variable percentage of these express citokeratin, $1,2,6,11,15,17$ which leads us to believe that the morphological change experienced by the cellular lineage could be influenced by the expression of these and other molecules from membranes as well as from cytoplasm.

Lauwers and cols ${ }^{18}$ (1998) found that the sarcoma-like zones had areas that were more aneuploid than the carcinomatous zones, and there was more biological activity, 
2. Rizzardi C, Frezzini C, Maglione M, Tirelli G, Melato M. A look at he biology of spindle cell squamous carcinoma of the oral cavity: report of a case. J Oral Maxillofac Surg 2003;61:264-8.

3. Marioni G, Bottin R, Staffieri A, Altavilla G. Spindle-cell tumours of the larynx: diagnostic pitfalls. A case report and review of the literature. Acta Otolaryngol 2003;123:86-90.

4. Petter G, Haustein UF. Histologic subtyping and malignancy assesment of cutaneous squamous cell carcinoma. Dermatol Surg 2000;26:521-30.

5. Guillen DR, Martin HL, Cockerell CJ. Cellular spindle cell proliferations of skin. Adv Dermatol 2001;17:339-84.

6. Handra-Luca A, Terris B, Couvelard A, Molas G, Degott C, Flejou JF. Spindle cell squamous carcinoma of the oesophagus: an analysis of 17 cases, with new inmunohistochemical evidence for a clonal origin. Histopathology 2001;39:125-32

7. Ansari-Lari MA, Hoque MO, Califano J, Westra WH. Inmunohistochemical p53 expression patterns in sarcomatoid carcinomas of the upper respiratory tract. Am / Surg Pathol 2002;26:1024-31.

8. Ballo MT, Garden AS, El-Naggar AK, Gillenwater AM, Morrison WH, Goepfert H, Ang KK. Radiation therapy for early stage (T1-T2) sarcomatoid carcinoma of true vocal cords: outcomes and patterns of failure. Laryngoscope 1998;108:760-3.

9. Olsen KD, Lewis JE, Suman VJ. Spindle cell carcinoma of the larynx and hypopharynx. Otolaryngol Head Neck Surg 1997;116:47-52.

10. Ferreras J, Junquera LM, Lopez JS, González M, Villarreal P, Cerrato E. Spindle cell carcinoma of the oral cavity. Report of a case. Med Oral 2000;5:47-53.

11. Slootweg P, Roholl $P$, Müller $H$, Lubsen $H$. Spindle-cell carcinoma of the oral cavity and larynx. Inmunohistochemical aspects. / Cranio-Max-Fac Surg 1989;17:234-6.

12. Lane N. Pseudosarcoma (polypoid sarcoma like masses) associated with squamous cell carcinoma. Cancer 1957;10:19-41.

13. Minckler DS, Meligro CH, Norris HT. Carcinosarcoma of the larynx. Case report with metastases of epidermoid and sarcomatous elements. Cancer 1970;26:195-200.

14. Sherwin RP, Strong MS, Vaughn CW. Polypoid and junctional squamous cell carcinoma of the tongue and larynx with spindle cell carcinoma («pseudosarcoma»). Cancer 1963;16:51-60.

15. Sigel JE, Skacel M, Bergfeld WF, House NS, Rabkin MS, Goldblum JR. The utility of cytokeratin $5 / 6$ in the recognition of cutaneous spindle cell squamous cell carcinoma. J Cutan Pathol 2001;28:520-4.

16. Ellis GL, Langloss JM, Heffner DK, Hyams VJ. Spindle-cell carcinoma of the aerodigestive tract. An inmunohistochemical analysis of 21 cases. Am / Surg Pathol 1987; 11:335.

17. Lewis J, Olsen K, Sebo T. Spindle cell carcinoma of the larynx: review of 26 cases including DNA content and inmunohistochemistry. Human Pathology 1997;28:664-73.

18. Lauwers G, Grant L, Scott G, Carr N, Sobin L. Spindle cell squamous carcinoma of the esophagus:analysis of ploidy and tumor proliferative activity in a series of 13 cases. Human Pathology 1998;29:863-8.

19. Kriskovich $M$, Harnsberger $H$, Haller J. Spindle cell carcinoma of the larynx. Ann Otol Rhinol Laryngol 1998;107:436-8.

20. Tse J, Aughton W, Zirkin R, Herman G. Spindle cell carcinoma of the oral mucosa. Case report with inmunoperoxidase and electron microscopic studies. J Oral Maxillofac Surg 1987;45:267-70.

21. Leventon GS, Evans HL. Sarcomatoid squamous cell carcinoma of mucous membranes of head and neck. A clinicopathologic study of 20 cases. Cancer 1981; 48:994-1003.

22. El-Mofty SK, Shannon MT, Mustoe TA. Lymph node metastasis in spindle cell carcinoma arising in odontogenic cyst. Report of a case. Oral Surg Oral Med Oral Pathol 1991;71:209-13. with the TPI (Tumoral Proliferative Index) registering by means of immunoreactivity, values of 0.44 for squamous areas and 0.68 for spindle areas. They report, in addition to this, a different DNA pattern, as low ploidy zones were found in squamous areas and low and high ploidy areas in spindle areas. This indicates a more aggressive clinical behavior. ${ }^{6}$

\section{Conclusions}

Spindle cell carcinoma is a rare variety of squamous cell carcinoma and it is thought to have an epithelial origin. It is found more commonly in the upper aerodigestive tract. It shows aggressive behavior and the rate of regional metastasis is not to be despised. Histological diagnosis is complicated, and resorting to immunohistochemical techniques and electron microscopy is often necessary.

\section{Acknowledgments}

To Dr. Ferreras Granado for the help and interest shown in the preparation of this article. 
23. Middlehurst RJ, Blackburn CW, Sloan P. Spindle-cell carcinoma: a case report. Britsh Journal of Oral and Maxillofacial Surgery 1990;28:114-6.

24. Suzuki H, Yamashiro K, Yoshida C, Fujioka Y. Carcinosarcoma of the tongue with cyclin D1 gene amplification. Arch Pathol Lab Med 2001;125:433-6.

25. Batsakis JG. Pseudosarcoma of the mucous membranes in the head and neck. The Journal of Laryngology and Otology 1981;95:311-316.

26. Lassaletta L, Alonso S, Granell J, Ballestín C, Serrano A, Álvarez-Vicent JJ. Synchronous glottic granular cell tumor and subglottic spindle cell carcinoma. Arch Otolaryngol Head Neck Surg 1998;124:10314.
27. Iascone C, Barreca M. Carcinosarcoma and pseudosarcoma of the esophagus: two names, one disease. Comprehensive review of the literature. World / Surg 1999;23:153-7.

28. Ahluwalia H, Gupta S. Pathology in focus. Spindle-cell carcinoma of the nasal septum. The Journal of Laryngology and Otology 1996;110:284-7.

29. Zarbo RJ, Crissman JD, Venkat H, Weiss MA. Spindle-cell carcinoma of the upper aerodigestive tract mucosa. An inmunohistochemical and ultrastructural study of 18 biphasic and comparison with 7 monophasic spindle-cell tumors. Am J Surg Pathol 1986;10:741.

30. Thompson L, Chang B, Barsky SH. Monoclonal origins of malignant mixed tumors (carcinosarcomas). Am J Surg Pathol 1996;20;277-85. 